\title{
Delineation of Stratigraphic Units In Xyz Field Of Niger Delta Using Geophysical Logs
}

\author{
Charles C. Ekeha, Etim D. Uko ${ }^{a}$, Ejiro F. Eleluworb and Friday B. Sigalo ${ }^{a}$ \\ a Department of Physics, Rivers State University, PMB 5080, Port Harcourt, Nigeria. \\ ${ }^{\mathrm{b}}$ Nigerian Agip Oil Company, Port Harcourt, Nigeria. \\ *Corresponding Author email: sirekeh@gmail.com, e_uko@yahoo.com, ejiro.eleluwor@naoc.agip.it, sigalo.friday@ust.edu.ng.
}

S sciendo

\section{DOI: 10.2478/pjg-2019-0005}

\begin{abstract}
:
Geophysical well logs were used to delineate the stratigraphic units and system tracks in the XYZ Field of the Niger Delta. The gross percentages for sand levels range from $93-96 \%$ in the shallow levels to $60-66 \%$ in the deeper levels. Porosity values ranged between $27 \%$ at shallower sections and $9 \%$ at deeper depths. Six depositional sequences were identified and categorized into their associated system tracts. Porosity decreases with depth in normal compacted formation for both sandstone and shale units. Surface porosity for sandstone is $42 \%$, and for shale it is $38.7 \%$ from extrapolation of sub-surface porosity values to the surface. The depth to the base of Benin Formation is highly variable ranging between 1300 and $2600 \mathrm{~m}$. This study reveals the possibility to correlate sand levels over long distances which enables inferring porosity values laterally. The knowledge of the existent stratigraphic units, the Benin, Agbada and Akata Formations and their petrophysical parameters such as porosity, lateral continuity of the sands and shales, the variation of the net-togross of sands with depth, enables the reservoir engineer to develop a plan for the number and location of the wells to be drilled into the reservoir, the rates of production that can be sustained for optimum recovery. The reservoir engineer can also estimate the productivity and ultimate recovery (reserves) using the results on this work.
\end{abstract}

Keywords: Stratigraphy, well logs, porosity, system tracts, Niger Delta, Nigeria.

\subsection{Introduction:}

The facies concept states that the sum total of the primary environment's significant characteristics of sediment is impacted on it by its environment of deposition [1]. The first dimension being the lithological correlation of sediments to build a stratigraphic picture of its development as sediments was being deposited. The second dimension is the building up of a structural profile of the sedimentation putting in cognizance the tectonic effects such as folding and faulting. The recognition of the third dimension in the vertical profile helps to reconstruct the detailed picture of interacting and interrelated subenvironments that cannot be obtained by simple comparison of lithological characteristics of different modern environments [2].

The aim of this study is to delineate the major stratigraphic units and system tracks in the study area of the Niger Delta, using porosity relationships with depth, sand/shale percentage relationship with depth, marking out stratified sequences using lithology logs. The application of sequence Stratigraphy techniques to sedimentary basin analysis has led to a new method of dividing, analyzing and mapping sedimentary rock $[3,4]$. More bypassed stratigraphic traps can be discovered and identified. This in essence would considerably increase the discovery of hydrocarbon potential in the stu8dy area. Moreover, a better understanding of the depositional environment, lithological facies and various depositional sequences of area of study which could be extended laterally to a regional extent in the Niger Delta.

\subsection{Theoretical Background}

\subsection{Sequence Stratigraphy}

Sequence stratigraphy is the study of rock relationships within a Chronostratigraphic framework of repetitive, genetically related strata bounded by surfaces of erosional or non-deposition, or their correlative conformities [5]. It could also be defined broadly as the historical geology of stratified rocks. More importantly, sequence stratigraphy can be simply put as the subdivision of sedimentary basin fills into genetic packages bounded by unconformities and their correlative conformities [6,7]. Sequence stratigraphy is largely used to provide a chronostratigraphic framework for the correlation and mapping of sedimentary facies and for stratigraphic prediction.

The fundamental unit of sequence stratigraphy is the sequence, which is bounded by unconformities and their correlative conformities. However, a sequence represents one cycle of deposition bounded by non-marine erosion, deposited during one significant cycle of fall and rise of base level [8]. In the majority of basins, base level is controlled by sea-level and a sequence is the product of a cycle of fall and rise of relative sea-level. The increase or decrease in relative sea-level brings about transgression and regression respectively. Transgression is the landward movement of the shoreline due to the spread or extension of the sea over land areas while regression is the basinward movement of the shoreline due to retreat or contraction of the sea from land areas [9]. Different types of deposition and associated systems tracts characterize these two processes. However, sequences are basically classified into two types; type- 1 sequence which is formed when the rate of eustatic fall exceeds the rate of subsidence at shoreline break. The type- 2 sequence is generally formed when the rate of eustatic fall is slightly less than or equal to the rate of basin subsidence at the existing depositional shoreline break at the time of the eustatic fall [6].

\subsection{Lowstand Systems Tract}

The basal (stratigraphically oldest) systems tract in a type-1 depositional sequence is called the lowstand systems tract [6, 10, 11]. It is deposited during an interval of relative sea-level fall at the offlap break, and subsequently slow relative sea-level rise. Prior to the fall in relative sea-level, the rivers will have more-or-less maintained a graded river profile with an erosional upper portion and a depositional lower portion. When relative sea-level falls at the offlap break, the river profile must adjust to the lowered base level. The river incises into the previously deposited topsets, the alluvial plain, coastal plain and/or shelf deposits of the previous sequence. These reworked sediments, and the fluvial load from the hinterland, are delivered directly on to the previous highstand clinoform slope. Because the river is not free to avulse, the sediment is focused towards the same point on the slope. This is an inherently unstable situation, and sedimentation processes are dominated by large scale slope failure resulting in bypass of the slope and deposition of submarine fans in the basin. These processes continue to dominate the sedimentary record while relative sea-level is falling and the rivers system is forced to incise. The lowstand systems tract may consist of a basin-floor fan characterized by submarine fan deposits on the lower slope or basin floor, a slope fan characterized by turbidite and debris-flow deposition on the middle or the base of the slope, and a lowstand wedge is a topset clinoform system deposited during accelerating relative sea-level rise [12]. Figs. 1 shows the different depositional facies associated with lowstand systems tract. 


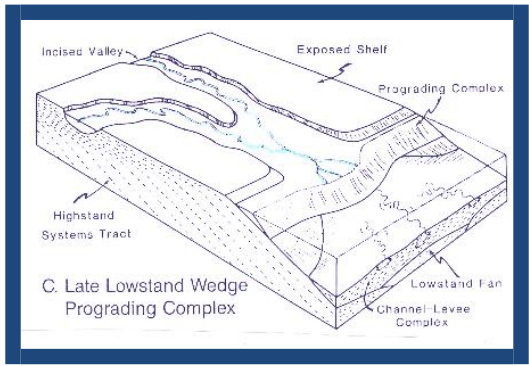

(a)

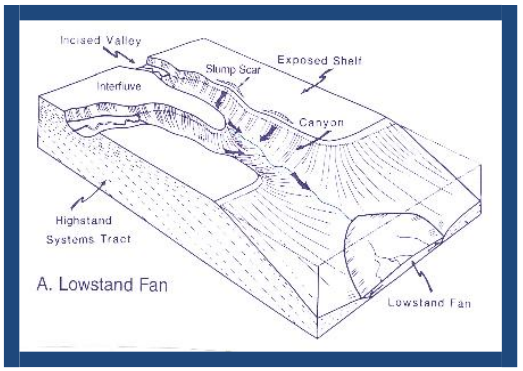

(b)

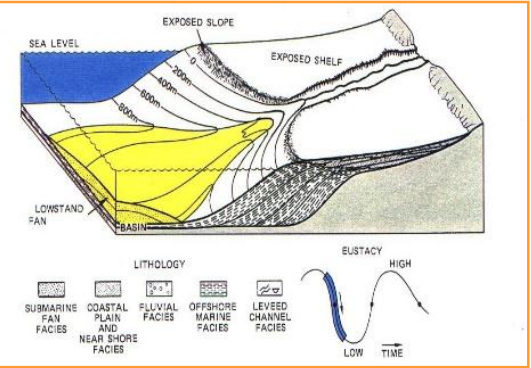

(c)

Figure 1: a) Prograding Lowstand, b) Slope-fan Lowstand System tracts, c) Basin-Floor Lowstand system tracts

The characteristics of Lowstand systems tract-prograding complex is characterized by Transition from upward shallowing to upward deepening, Toplap common below boundary, Transgressive surface of erosion on the shelf, Thick intervals of coarsening upward sands common near top, Shoreface and deltaic sands typical, Progrades laterally into bathyal hemipelagic shale, Pinches out near offlap break of underlying highstand, May contain shingled turbidite mounds at base, Minor Condensed Section, Maximum clay-shale point, Faunal abundance peak, and Downlap common above boundary [12].

\subsection{Transgressive Systems Tract}

This is deposited during that part of a relative sea-level rise cycle when topset accommodation volume is increasing faster than the rate of sediment supply. Transgressive systems tract is bounded below by the transgressive surface and above by the downlap surface or maximum flooding surface [13,14]. Parasequences within the transgressive systems tract backstep in a retrogradational parasequence set. The maximum rate of rise of relative sea-level occurs sometime within the transgressive systems tract, and the end of the systems tract occurs when the rate of topset accommodation volume decreases to a point where it just matches sediment supply, and progradation begins again. This point is known as the maximum flooding surface [15]. Fig. 2 shows a typical illustration of Transgressive, systems tract. Topsets of the transgressive systems tract tend to have a lower sand percentage than those of other systems tracts, because little of the mud-grade sediment bypasses the topsets $[6,16]$.
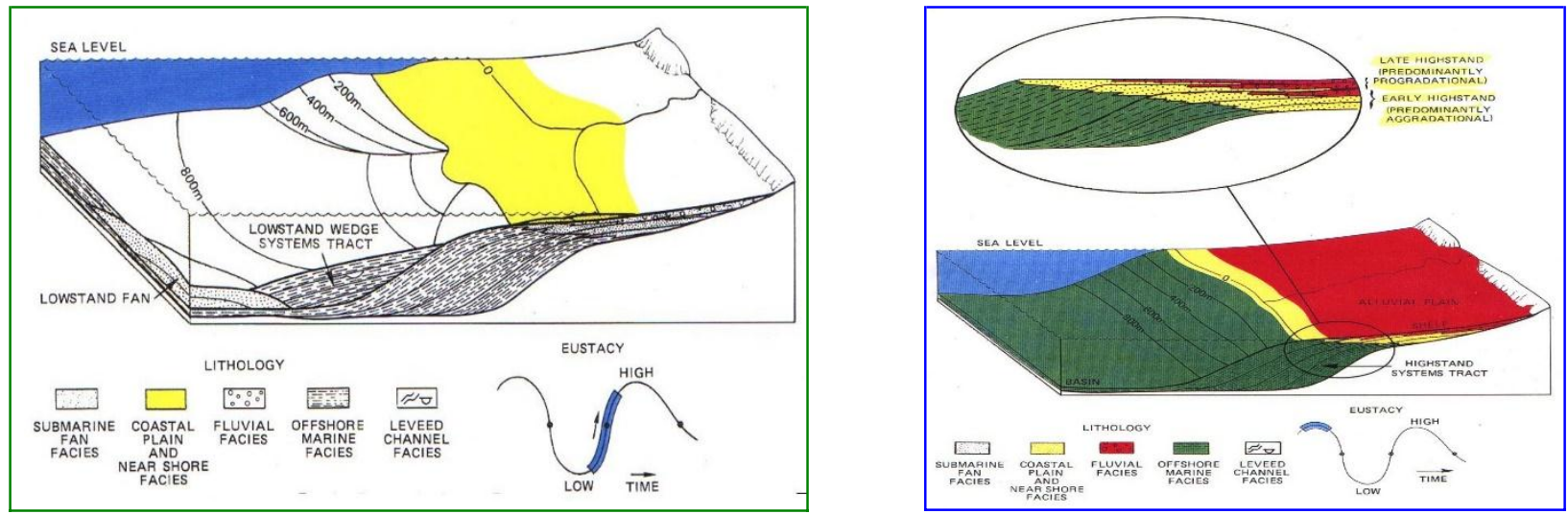

Figure 2: a) Transgressive System Tract [12], b) Highstand System Tracts [12]

The characteristics of Transgressive systems tract is characteristerized by Commonly lowest resistivity-highest gamma; Most clay rich shale (most starved); Faunal abundance peak; Apparent truncation common below boundary; Downlap common above boundary; Individual parasequences prograde, fine and thin upward (backstep); Beach and shoreface sands common near base; Basinal equivalent is thin hemipelagic shale; Correlation is good, but backstepping transgressive surface of erosion are time-transgressive; Sands often better sorted than HST; Authigenic minerals common; Onlaps sequence boundary; Commonly transgressive surface of erosion (ravinement surface) over older shelf sediments near shelf edge; and Non-marine sediments (coastal plain, coal or lake sediments) onlap sequence boundary in more landward areas [12].

\subsection{Highstand Systems Tract}

It is a systems tract bounded below by the downlap surfaces above by next sequence boundary. The early highstand commonly consists of an aggradational parasequence set; the late highstand is composed of one or more progradational parasequence sets. The highstand systems tract is the youngest systems tract in either a type-1 or a type-2 sequences [6]. It is characterized by decelerating rate of relative sea-level rise through time, resulting in initial aggradational and later progradational architecture. Fig. 2 shows the typical diagrammatical illustration of highstand systems tract. Depositional systems may be similar initially to those in the transgressive systems tract, but the infill of shelf areas by progradation, and the decrease in the rate of relative sealevel rise, may lead to a decrease in tidal influence during a highstand systems tract, and a decrease in the amount of coal, and of overbank, lagoonal and lacustrine shales $[7,9]$.

A depositional sequence represents a complete cycle of deposition bounded above and below by erosional unconformities. The sequence has a maximum duration, which is measured between the correlative conformities to the bounding unconformities. Thus, the duration of the sequence is determined by the event controlling the creation and destruction of accommodation i.e tectonic subsidence and/or eustacy [17]. Tectonic cycles of subsidence and uplift and eustacy cycles of rising and falling sea-level can operate over different time periods, and it is useful to classify sequences in terms of their order of duration, commonly termed first, second, third and fourth order. A basin-fill can then be divided into a hierarchy of sequences, each representing the product of a particular order of tectonic or eustatic cycle.

The characteristics of Highstand systems tract include $[18,19]$ are: Onlap above boundary, Lowstand erosion on shelf, Incised valleys on shelf, Canyon cuts and slump scars on upper slope, Truncation or toplap below boundary, Fluvial (meandering streams, alluvial fans) below boundary in more landward areas, Coarsening and shallowing upward sand and silt interbedded, Shoreface \& deltaic sands near top, Progrades laterally into offshore shales, Basinal equivalent is hemipelagic shales, Log correlation is difficult in upper part, Reservoir continuity is fair to poor, Common lowest resistivity-highest gamma, Most clay rich shale (most starved), Faunal abundance peak, Downlap common above boundary, and Apparent truncation common below boundary.

Four orders of stratigraphic cycles are depicted [20]. The continental encroachment cycle is defined by the very largest scale ( $>50$ million years) cycles of sedimentary onlap and offlap of the super continents. There are only two such cycles in the phanerozoic, according to the Haack et al. [21] sea level curve. First-order continental encroachment cycles are considered to be controlled by tectono-eustasy i.e changes in ocean basin volume related to plate tectonic 
cycles. Second order (3-50 million years) cycles are the building blocks of the first-order sequences and represent particular stages in the evolution of a basin. They are caused by changes in the rate of tectonic subsidence in the basin or rate of uplift in the sediment source terrain.

Third order ( 0.5 - 3 million years) sequence cycles are the foundation of sequence stratigraphy because they are often of a scale well-resolved by seismic data. They are identified by the recognition of individual cycles of accommodation creation and destruction. These cycles are considered by Vail [12] to be controlled by glacio-eustacy, although other tectonic mechanisms are possible. Fourth order $(0.1-0.5$ million years) parasequence cycles represent individual shallowing upward facies cycles bounded by surfaces of abrupt deepening. These may be related in part to autocyclic processes within the sedimentary system.

\subsection{Study Area and Its Geology}

The area of study is located in the Central Swamp of the Niger Delta (Fig. 3). The area falls between Latitudes $6^{\circ} 10^{\prime} \mathrm{N}-6^{\circ} 30^{\prime} \mathrm{N}$ and Longitudes $4^{\circ} 40^{\prime} \mathrm{E}-$ $4^{\circ} 60^{\prime} \mathrm{E}$. The wells drilled around the location are fairly deep penetrating both the Benin and Agbada Formations of the Niger Delta.

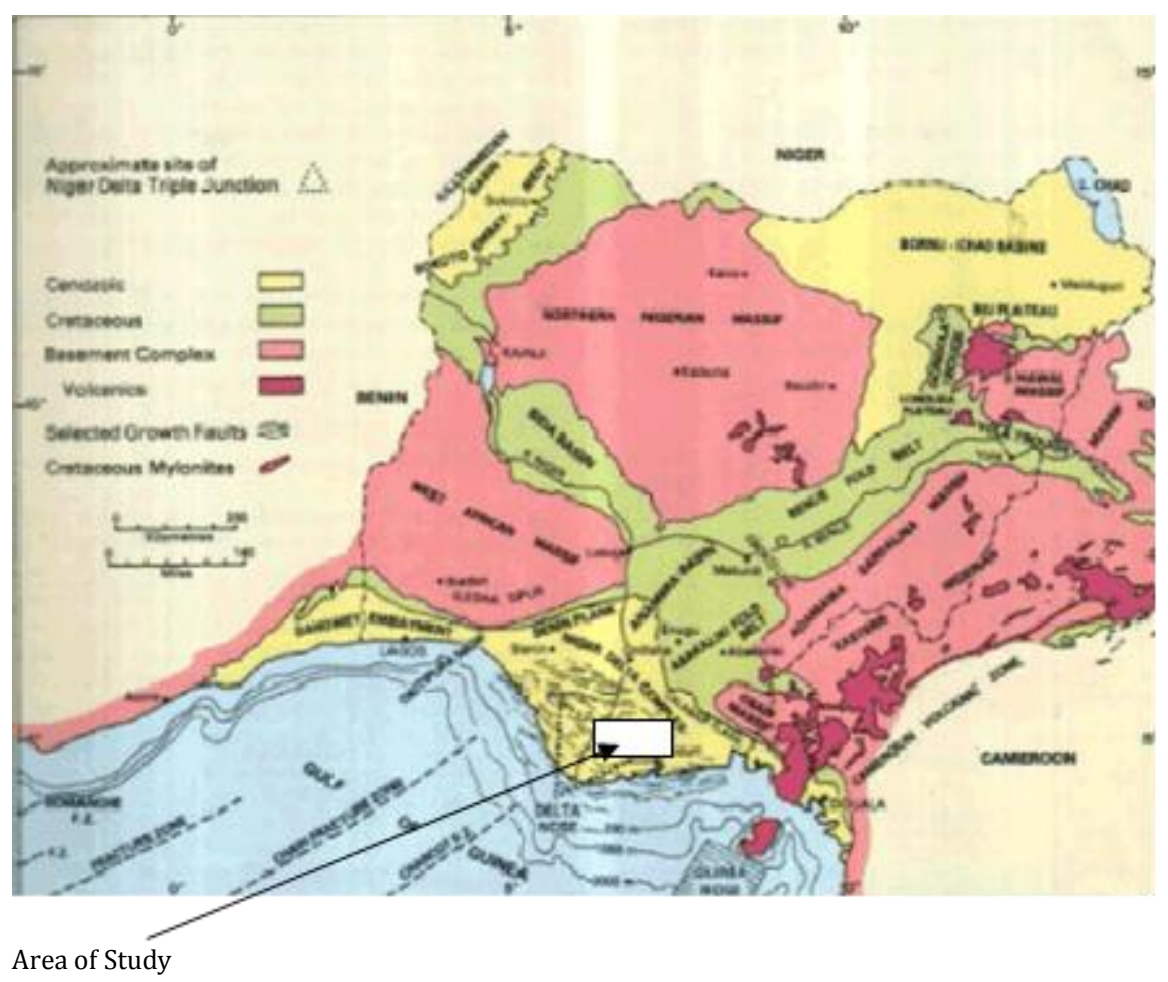

Figure 3: Geologic map of Nigeria showing location of Niger Delta and the Area of Study [22].

The Niger delta has built out over the collapsed continental margin, and its core is located above the collapsed continental margin at the site of the triple junction formed during the middle Cretaceous. The main sediment supply has been provided by an extensive drainage system, which in its lower reaches follows two failed rift arms, the Benue and Bida basins. Sediment input generally has been continuous since the late Cretaceous, but the regressive the north and east during most of the Tertiary, even though there is little evidence for substantial Tertiary uplift in much of the catchment area of the Niger-Benue river systems. The inland drainage system of the Niger was captured by the Lower Niger in the Quaternary, prior to which the Upper Niger drainage fed the continental interior basins of Mali. The Benue and Cross rivers, though shorter than the Niger, have been draining areas of greater relief throughout the Tertiary, and have supplied a substantial amount of volcanic detritus from the Cameroon volcanic zone since the Miocene (Fig. 3). The Niger delta has prograded into the Gulf of Guinea at a steadily increasing rate in response to the evolving drainage area, basement subsidence, and eustatic sea-level changes. Initially, the delta prograded over extensionally thinned and collapsed continental crust of the West African margins as far as the triple junction, filling in the basement graben-and-horst topography. The convex-to-the-sea morphology did not develop until the Eocene.

Regression has been rapid since then, and increasing volumes of sediment have been deposited since the Oligocene. The Niger delta is a typical vave and tidal dominated delta. At present, it appears to be constructive in the centre and destructive on either flank. The coast is 50km landward of its position during Pleistocene lowstands because of a eustatic rise in sea level of about $90 \mathrm{~m}$ in the last 75,000 years [23]. One of the most striking features of the delta is the very sandy nature of the sediments. This is partly a result of the fact that nearly all of the environments in the sub-aerial part are of upper coastal or delta plain origin, but is also a result of the very sandy sediments supply. The sediment source areas in the shield consist mainly of crystalline rocks of the Guinea Highlands basement complex, with Cretaceous and Tertiary sediments derived from them and material derived from the Cameroon volcanic zone. The quality and abundance of reservoirs throughout the Tertiary sequence indicates that there has always been a major sand contribution from the shield areas. Much of the sediment carried by the upper reaches of the Niger River is, or has been, deposited in the interior lake basin of Timbucktoo, but an annual discharge of 19 million $\mathrm{m} 3$ of sediment (of which 1 million $\mathrm{m} 3$ is sand) enters the delta at Onitsha. The annual water discharge at the same station is as much as 300 billion $\mathrm{m} 3$, or about $40 \%$ of the discharge of the Mississippi River [23].

The lower delta plain consists of a central constructive portion, occupied by the main distributary channels, the Forcados and Nun rivers. On either side, large salt-water mangrove swamps, covering an area of about $10,000 \mathrm{~km} 2$, which extend as far as $25 \mathrm{~km}$ inland, characterize the destructive portions of the delta. In these areas there is less discharge of fresh water and a dominance of tidal influences. Longshore currents carry sediments discharged at the apex of the delta both north-westward and eastward along the coast to form sandy beaches, beach ridges, and offshore bars [24]. The marginal areas of the delta are relatively starved of sands and in places suffer encroachment from the sea. The submarine portion of the delta consists of a broad, shallow shelf which gradually merges into a long continental slope and rise extending as far as $250 \mathrm{~km}$ from the coast. The upper part of the slope is marked by a zone of faulted sediments, clay walls and diapers, known as the distal belt because it represents the outermost portion of the developed part of the delta.

The three major formations that made up the present Niger Delta are: The Benin Formation which is about $1800 \mathrm{~m}-2000 \mathrm{~m}$ thick. It is the youngest and shallowest part of the sequence and composed almost entirely of non-marine sand. It was deposited in alluvial or upper coastal plain environments following a southward shift of deltaic deposition into a new depo-belt. The Benin Formation first occurred in the Oligocene times in the northern delta sector, although they lack fauna, they are impossible to date directly. Offshore, they become thinner and disappear near the shelf edge [25]. Chronologically, Agbada Formation is next to Benin Formation, that is about $1000 \mathrm{~m}-1500 \mathrm{~m}$ thick, an alternation of sands, silts and shales, in various proportions and 
thickness, representing cyclic sequences of offlap units. This forms the hydrocarbon-prospective sequence in the Niger delta. The paralic clastic are the truly deltaic portion of the sequence and were deposited in a number of delta-front, delta-topset, and fluvio- deltaic environments. The alternation of fine and coarse elastics provides multiple reservoir seal couplets [25]. The oldest deposits of the Agbada Formation are of Eocene age in the North and are presently being deposited in the near shore shelf domain.

The last sedimentary sequence is the over pressured shales of the Akata Formation, of which thickness may reach about $7000 \mathrm{~m}$ in the central part of the delta. This lithofacies is composed of shales, clays and silts at the base of the known delta sequence. They contain a few streaks of sand, possibly of turbiditic origin, and were deposited in holomarine (delta-front to deeper marine) environments. Marine shales form the base of the sequence in each depobelt and range from Palaeocene to Holocene in age. They crop out offshore in diapers along the continental slope, and onshore in the north-eastern part of the delta, where they are known as the Imo shale [25]. Fig. 4 shows the schematic structural section through tripartite division of the Tertiary sequence to basement in the Niger delta.

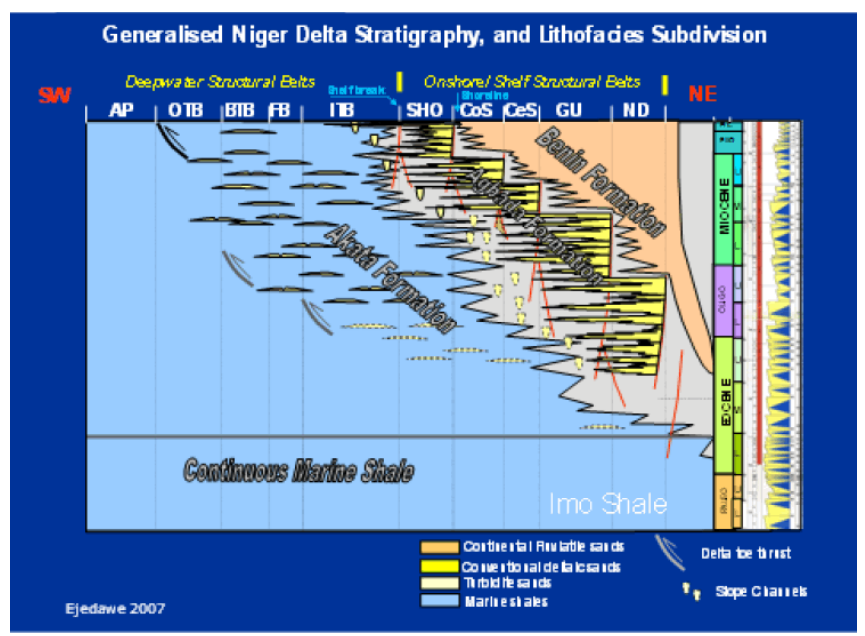

Figure 4: Schematic structural section across the Niger Delta [25].

\subsection{Materials And Methods}

\subsection{Determination of Sandstone and Shale Lithology}

A composite log comprising Gamma-ray log (Fig. 5) was used to delineate the lithologies at the pre-determined depth intervals. The American Petroleum Institute (API) values ranges from sandstone line 0 to shale line 125 . As the signature of the log move towards the higher values, the formation becomes shalier. The delineation approach enabled us to estimate and establish the lithological sequence of the formation of the study area.

To determine the ratio of sand to shale of the subsurface geology of the study area, Gamma ray log run for the different wells were delineated into sections with two litho faces, namely, sandstones and shale. The gamma ray log reflects the shale content of sedimentary formations. Clean sandstones and carbonates normally exhibit a low level of natural radioactivity, while clay minerals and fluid particles in shales show higher levels of radioactivity due to adsorption of the heavy radioactive elements. Basically gamma ray log is useful for location of shales and non-shaly beds and most importantly, for general correlation [22].

Clean sandstones were delineated as with log signatures increasing towards the sand-line that is low API unit ranging between 0 and 20 API units. For sandy-shales it ranges from 20 to 100 API units. While shales have API unit values of 100 and above with log signatures moving towards the shale line showing decrease in rate of sedimentation and overall decrease in energy; identified as fluvial environments and transgress sequences. Indicative net-togross maps based on deltaic sedimentary elements distribution at varying depths in the study area were produced using Landmark's ZMAP software. Net to gross percentages of the sands for Levels A - E, starting from the shallower Levels A to the deeper Level E were also mapped.

The amount of each lithofacies was then estimated by counting the interval of a particular lithofacies and then assigns a fraction of this to the total interval within the sand-shale lines which then expressed as a percentage. Checking the quality of the gamma ray log with the response of the density log, it was observed that the gamma ray adequately separates sands from shale as shown in Fig. 5 . The percentages of sandstones and shales were estimated using Gamma ray logs, Fig. 5. The API values indicate sand and shale domains. From the Header of the log, the API values ranges from 0 to 125 . As the values increases, the formation lithology becomes shalier.

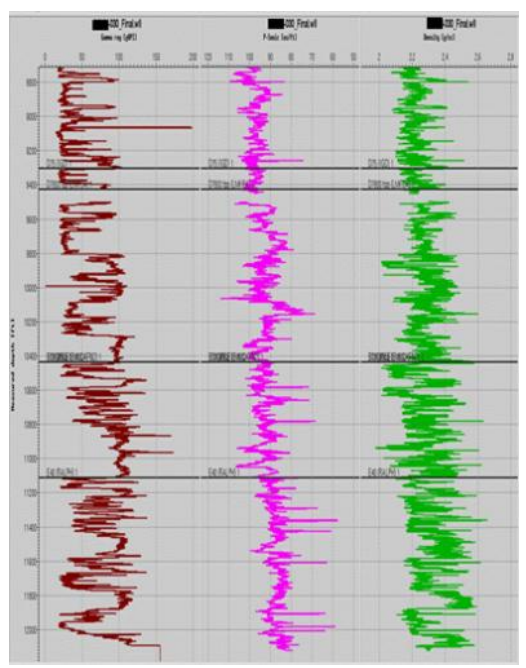


Figure 5: An example of Well log used for sandstone and shale lithology

\subsection{Determination of Porosity}

It is generally accepted among geoscientists that porosity calculation from bulk density logs is more accurate [26]. To calculate the porosity, [? , we use the rock matrix density, ? $\mathrm{ma}$, the fluid density, ?f f and the bulk density, ?b. The average rock density in the sandstones research reports is $2.66 \mathrm{gcm}-3$. The average rock density in the shales is $2.65 \mathrm{gcm}-3$. The fluid density depends on whether the well encountered water or hydrocarbons. This was determined by the electrical resistivity log. The hydrocarbon density was calculated from composition and phase considerations, oil $=0.80 \mathrm{gcm}-3 \mathrm{and}$ gas $=0.6 \mathrm{gcm}-3$. The water density used was $1 \mathrm{gcm}-3$. If Gamma Ray value is below a threshold value, in our case $100 \mathrm{GAPI}$, the lithology is interpreted to be sandstone, Fig. 5. Porosity was determined from the formula [27]:

$$
\phi_{\text {density }} L \frac{\rho_{m a}-\rho_{b}}{\rho_{m a}-\rho_{f}}
$$

where $\rho_{\mathrm{ma}}=$ matrix (or grain) density, $\rho_{\mathrm{f}}=\mathrm{fl} \mathrm{u}$ i d density and $\rho_{\mathrm{b}}=$ bulk density (as measured by the tool and hence includes porosity and grain density .

Porosity maps were produced from porosity data derived from selected wells in the study area, using Landmark's ZMAP software. Five sand levels (A - E) with increasing depth from the surface were mapped. Porosity versus depth cross plots were also plotted for 3 areas of study area. Gamma ray and Spontaneous potential logs. Resistivity and Sonic data for nine representative wells in the study area were loaded and plotted against depth using Microsoft Excel spreadsheet. These plots were used in inferring the base of the Benin, Agbada and Akata Formations as there is an abrupt deflection in the trend of the curves.

\subsection{Delineation of Stratigraphic Unis using Resistivity and Sonic Logs}

Resistivity and Sonic logs were loaded and plotted against depth using Microsoft Excel spreadsheet. These plots were used to infer the base of Benin Formation indicated when there is an abrupt deflection in the trend of the curve. Resistivity trend line changes when it passes from fresh water Benin Formation to salt water in the Agbada Formation.

\subsection{Delineation of Stratigraphic Units using Well Correlations}

Wells were correlated in the study area. Some wells had good correlation. The base of the Benin Formation was taken in all the wells in the study area. This was taken based on the theory that continentally-derived sediments carry fresh water while marine-derived sediments contain water of high salinity levels. Working with the resistivity logs and sonic logs of wells in the study area, lowstand, highstand and stratigraphic units were established.

\subsection{Sequence Stratigraphy}

The depositional sequence is the basic unit of sequence stratigraphy. Self-potential (SP) and Gamma-ray (GR) logs form the basis for subdividing the stratigraphy into genetic units as well as the interpretation of depositional environments and sand bodies. In the analysis of well logs, maximum flooding surfaces and sequence boundaries were identified. The surfaces were used to delineate the different genetic units inside which systems tracts were recognized. These systems tracts were in turn composed of parasequences. A parasequence is a series of layers or groups of layers some meters or tens of meters thick and bounded by marine flooding surfaces. Up to 6 composite genetic units were identified based on log characteristics, from $1500 \mathrm{~m}$ to reference well's total depth. Each parasequence is characterized by a regressive facies trend (shallowing upwards), which can be either positive or negative (fining or coarsening upward).

\subsection{Results and Discussion}

\subsection{Net-to-gross Sand Percentage with Depth}

Indicative net-to-gross maps based on deltaic sedimentary elements distribution at varying depths in the study area were produced using Landmark's ZMAP software. Net-to-gross percentages of the sands for Levels A - E, starting from the shallower Levels A to the deeper Level $\mathrm{E}$ was also mapped. These maps are shown in Figs. 6-10. The percentages range from $93-96 \%$ in the shallow levels to $60-66 \%$ in the deeper levels mapped. It was observed that the net to gross for sands was reducing with depth, indicative of an increased shaliness of the Niger Delta with depth.

\subsection{Porosity Variation with Depth}

Porosity maps produced from porosity data derived from selected wells in the study area, using Landmark's ZMAP software are here presented. Five sand levels (A - E) with increasing depth from the surface were mapped. Results from porosity calculations are shown in Figs 11 - 15, and puts the porosity values to range from between $9 \%$ at the deeper section E to $27 \%$ at the shallower section A of the study area. Porosity versus depth cross plots were also plotted for $3 \mathrm{X}, \mathrm{Y}, \mathrm{Z}$ areas of study area. Gamma ray and Spontaneous potential logs, together with Resistivity logs were used to mark-up the base of the Benin Formation, which in most wells in the area was been $1800-2300 \mathrm{~m}$. Porosity values were plotted from a depth of $1800 \mathrm{~m}$ downwards. The general porosity trend was obtained as shown on Figs. 16 and 17. Porosities show a generally linear relationship with depth.
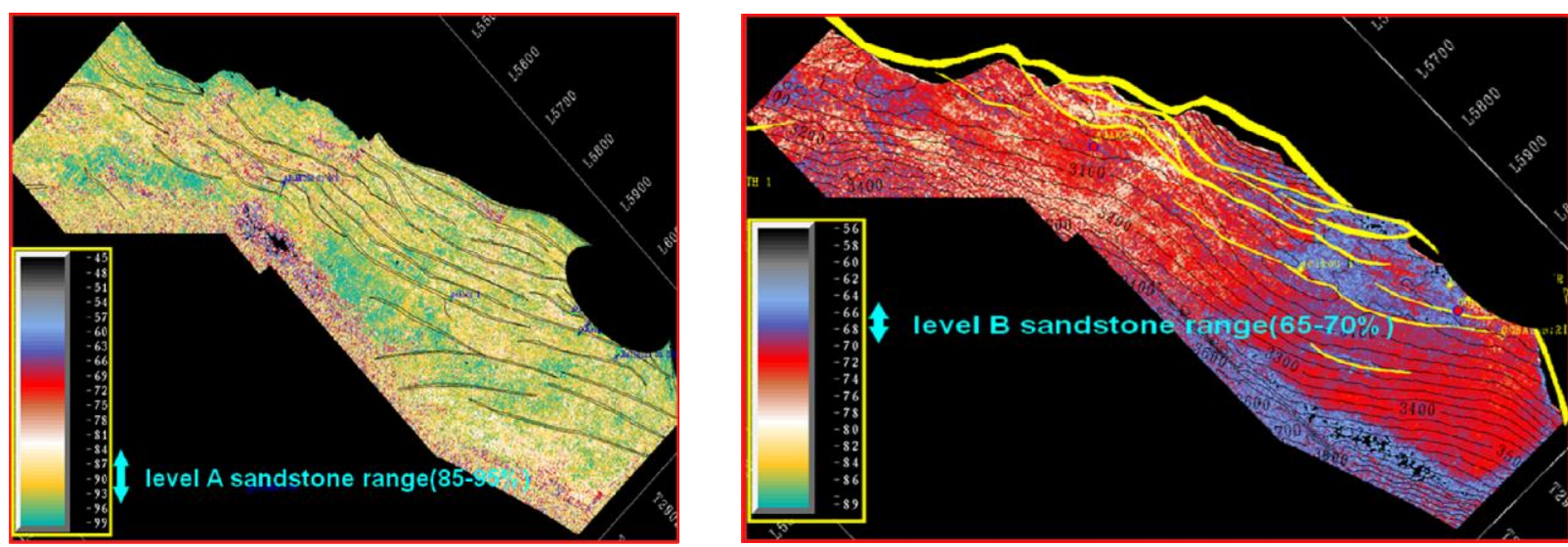

Figure 6: Net-to-gross sandstone percentage of Level

Figure 7: Net-to-gross sandstone percentage of Level B 


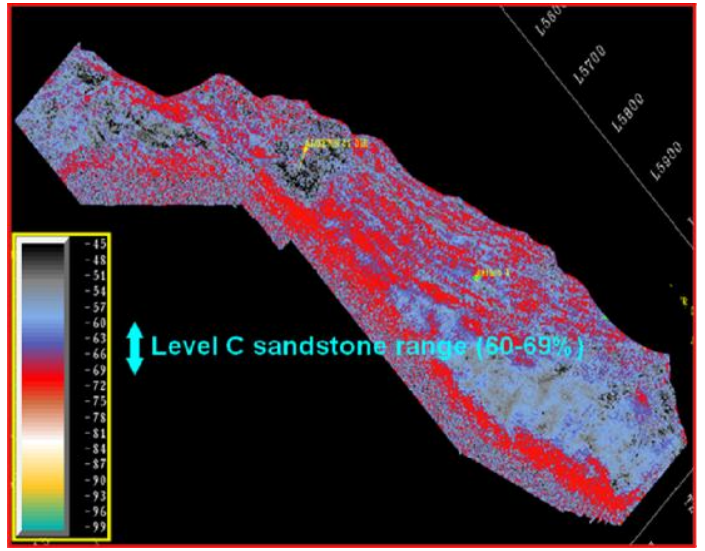

Figure 8: Net-to-gross sandstone percentage of Level C

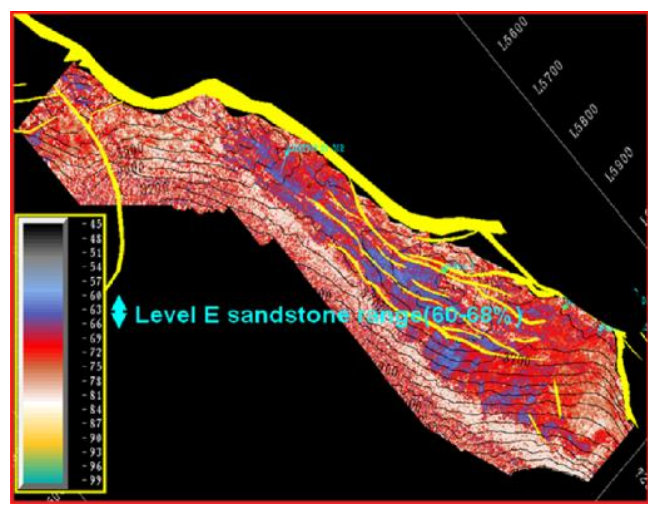

Figure 10: Net-gross sandstone percentage of LevelE

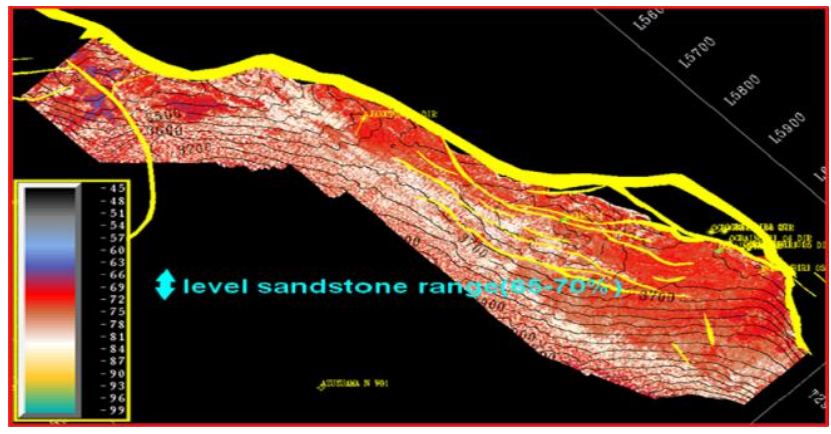

Figure 9: Net-to-gross sandstone percentage of Level D

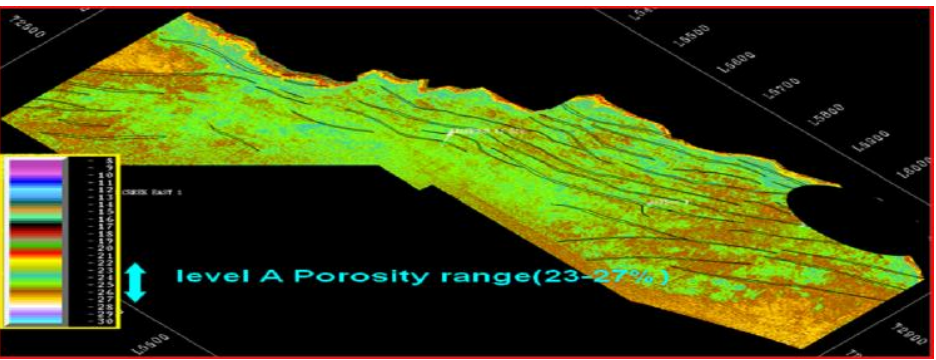

Figure 11: Porosity map for Level A 2500-3000m depth.

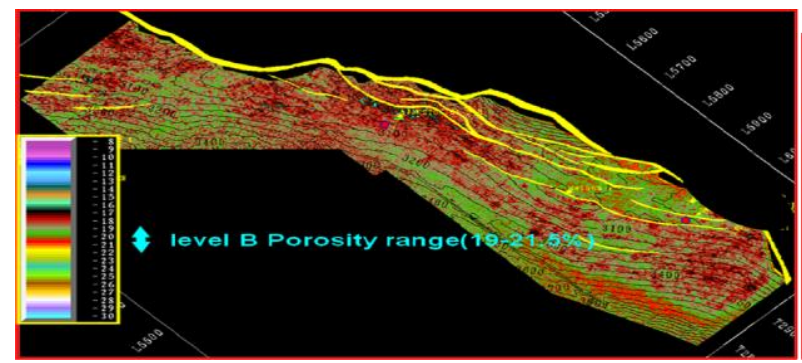

Figure 12: Porosity map for Level B 2800-3400m depth.

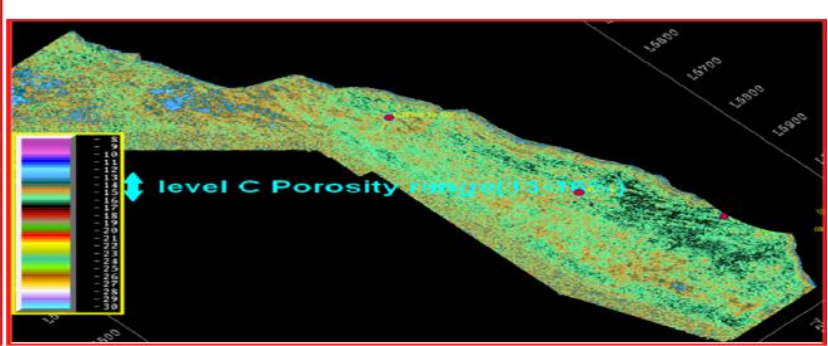

Figure 13: Porosity map for Level C 2900-3600m depth.

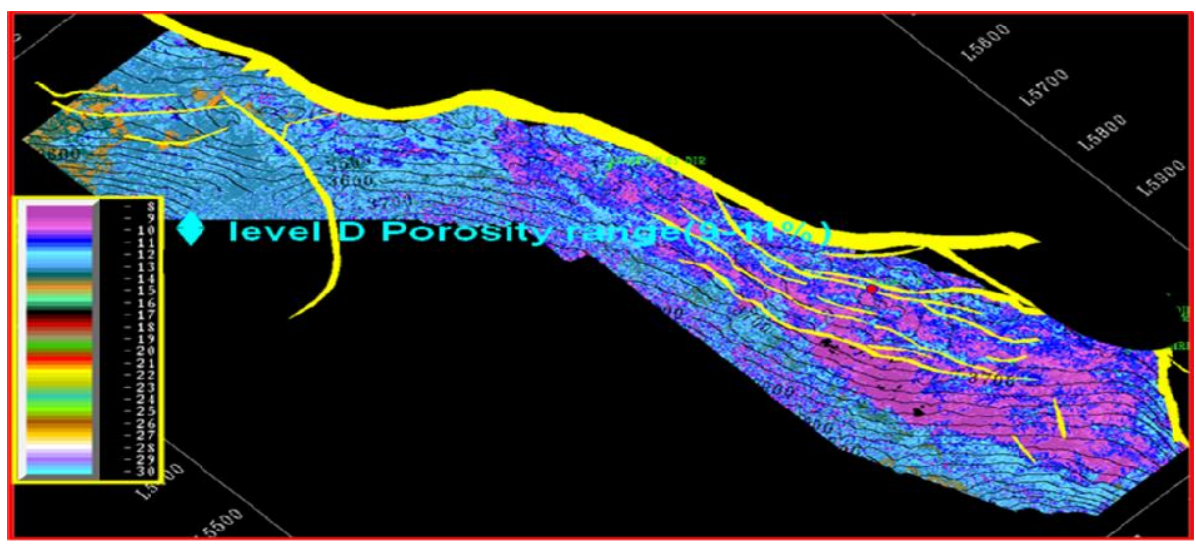

Figure 14: Porosity map for Level D 3000-3900m depth. 


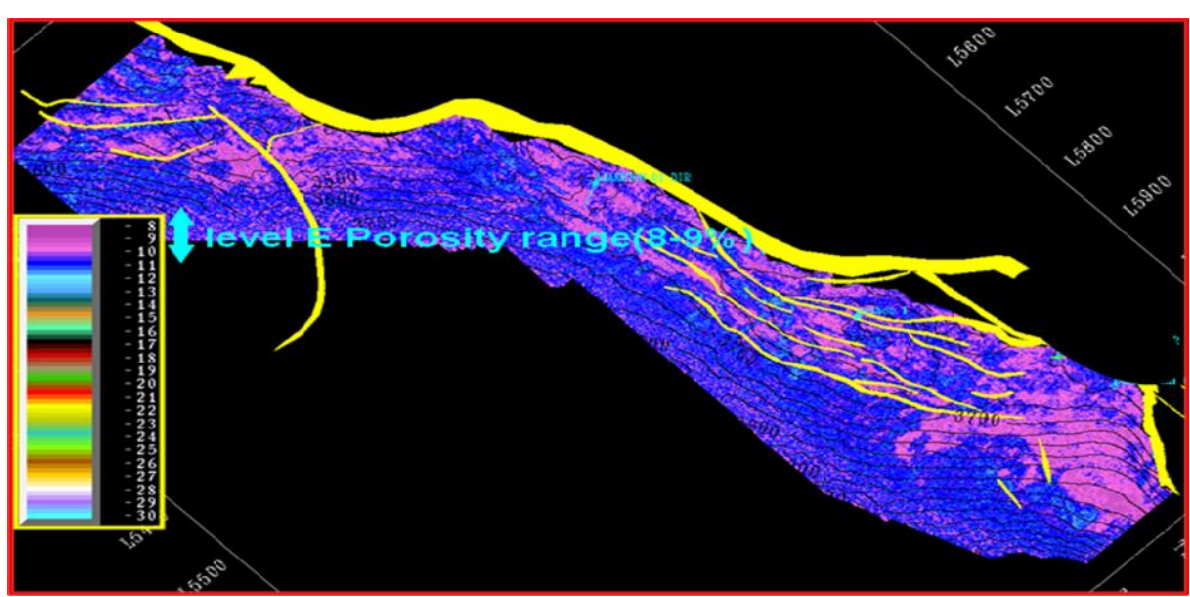

Figure 15: Porosity map for Level E 3200-4200m depth.

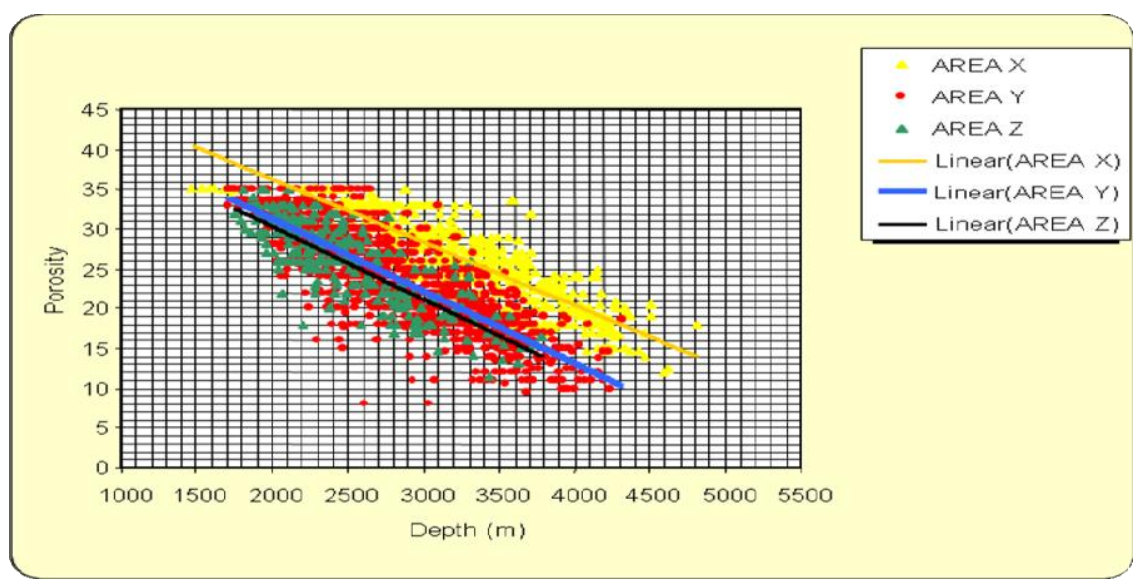

Figure 16: Maximum Porosity-Depth profile for X, Y, and Y sub-areas of The Study Area

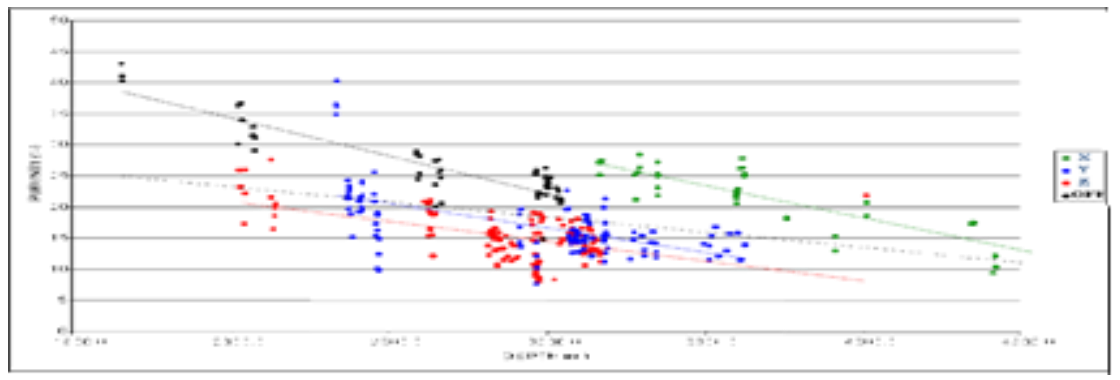

Figure 17: Minimum Porosity-Depth profile for X, Y, and Y sub-areas of The Study Area

\subsection{Delineation of Stratigraphic Units using Resistivity and Sonic Logs}

The cross-plots Resistivity and Sonic logs against depth are presented in Figs. 18-26. They show the relationship between the Resistivity and Sonic; the depth of the wells ranges from $3500 \mathrm{~m}$ to $5000 \mathrm{~m}$. These plots were used in inferring the base of the Benin, Agbada and Akata Formations boundaries. Working with Resistivity, gamma-ray and well-correlation data, the base of Benin Formation is marked at 1300-2600m (Fig. 27). The bases of Agbada and Akata Formations could not be established because none of the wells penetrated them.

\subsection{Delineation of Stratigraphic Units using Well Correlations8}

Five levels (A - E) with increasing depth from the surface were correlated, and intervals between ranged between 1.83 to $12.37 \mathrm{~km}$. The results of the correlations are shown in Figs. 28 - 33.

\subsection{Sequence Stratigraphy}

A genetic depositional sequence comprises the system tracts, Highstand Systems Tract (HST), Lowstand Systems Tract (LST) and Transgressive Systems Tract (TST) have been defined by the capping Maximum Flooding Surfaces (MFS). Fig. 34 shows the MFS1 to MFS5 as defined on seismic section based on the interpretation. With the aid of seismic data and available biostratigraphic information, regional geologic correlation has been carried out across the area from Well-1 through Wells 2 and 3 up to Well 4.

Seven important regional flooding surfaces were identified and found within hemipelagic shales, identifiable on logs with high gamma ray and low resistivity. The varying depths at which these shales were found are shown in Table 1 . These shales were used as important regional markers for seismic interpretation and formed the basis for sequence definition. Two of these shales are indicated by biostratigraphic studies to be linked to global maximum flooding surfaces (MFS) at $9.5 \mathrm{Ma}$ and $10.4 \mathrm{Ma}$. 

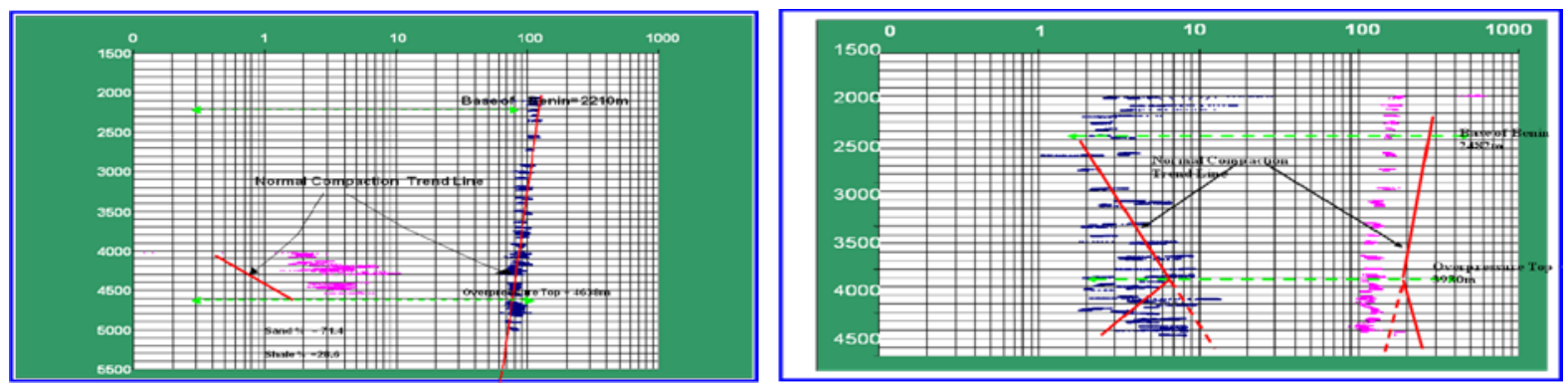

Figure 18: Depth-porosity/resistivity profile for Well X2

Figure 19: Depth-porosity/resistivity profile for Well X5
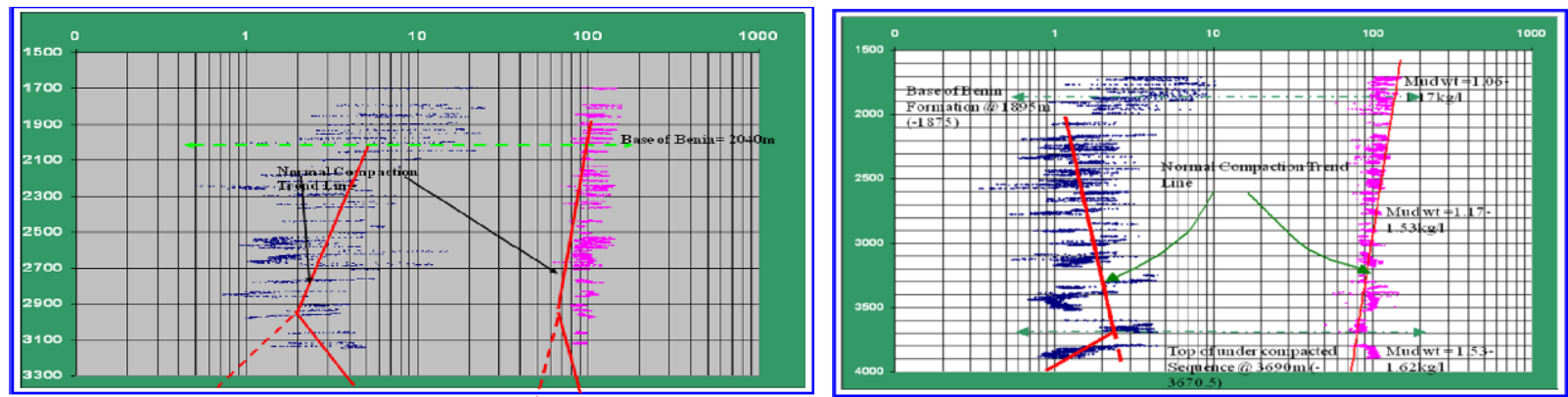

Figure 20: Depth-porosity/resistivity profile for Well X8

Figure 21: Depth-porosity/resistivity profile for Well X11
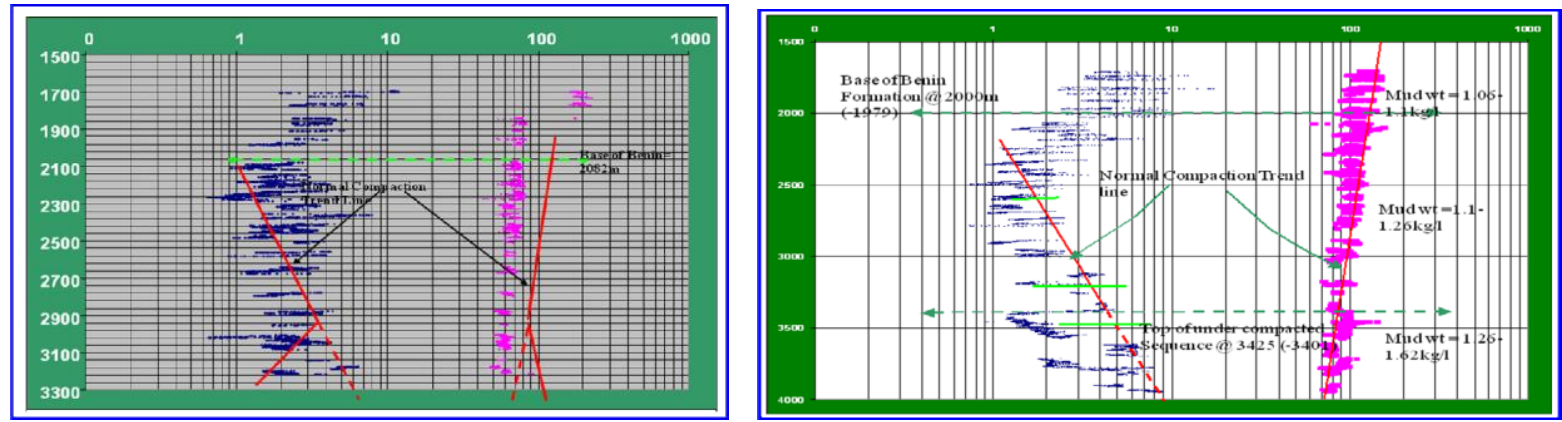

Figure 22: Depth-porosity/resistivity profile for Well Y1

Figure 23: Depth-porosity/resistivity profile for Well Y3
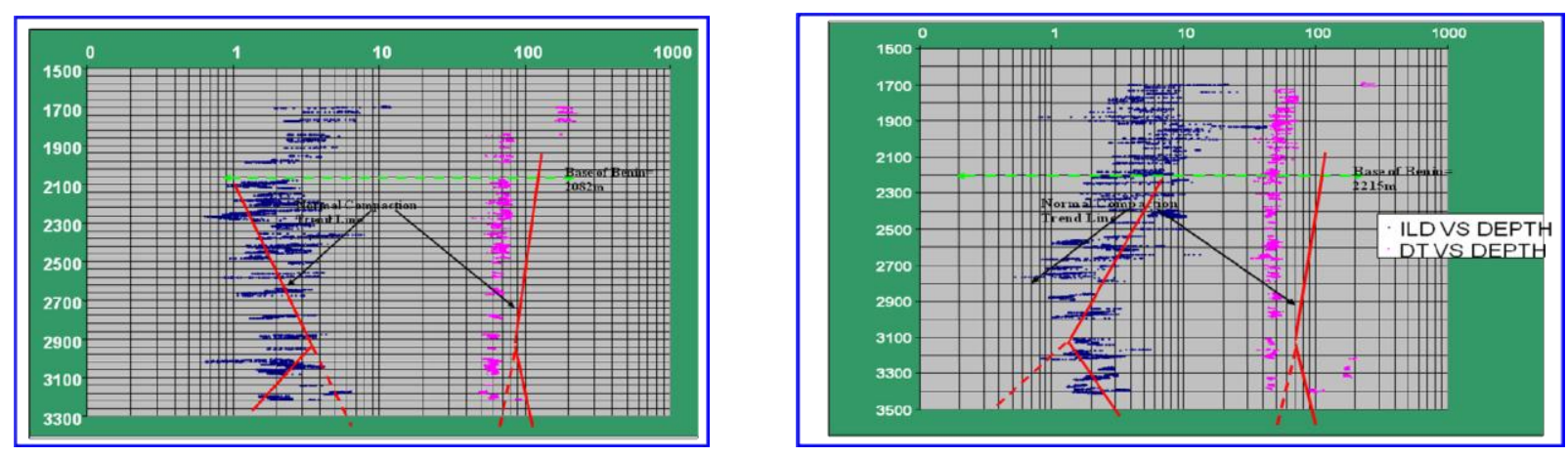

Figure 24: Depth-porosity/resistivity profile for Well Z1

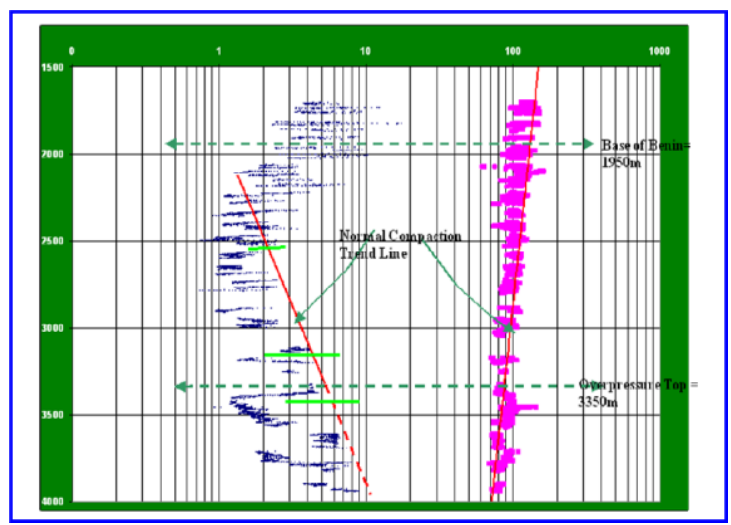

Figure 25: Depth-porosity/resistivity profile for Well Z2

Figure 26: Depth-porosity/resistivity profile for Well Z3 


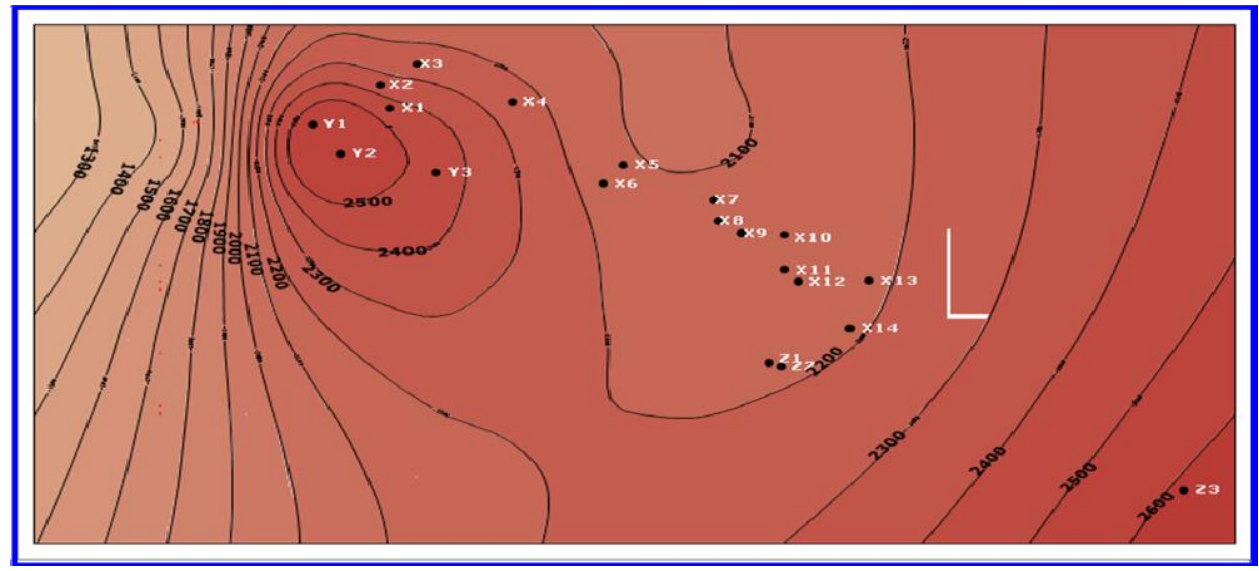

Figure 27: Contour Map of the Base of Benin Formation from Well Log Data

Six depositional sequences are identified, correlated and delineated. The Sequences are further divided into para-sequences and their associated systems tracts, namely Highstand systems tract (HST), Lowstand systems tract (LST) and Transgressive systems tract (TST). The Systems tracts of the study area are shown in Table 1 and Fig. 34. In sequence 6, the top boundary could not be identified due to lack of reliable biostratigraphic data within the shallow interval analyzed wells. The description of these Sequences and available biostratigraphic data is presented below.

Table 1: Depositional Sequences and associated System Tracts

\begin{tabular}{|c|c|c|c|c|c|c|}
\hline & & Well X1 & & Well X2 & Well X3 & Well X4 \\
\hline \multirow[t]{2}{*}{ Sequence 1} & HST1 & 4367.0-TD & & Not reached & Not reached & 4257.0-TD \\
\hline & TST1 & $4340.0-4367.0$ & & Not reached & Not reached & $4160.0-4207$ \\
\hline \multirow[t]{2}{*}{ Sequence 2} & HST2 & $3927.0-4340.0$ & & 4440.0-TD & 4085.0-TD & $3807.0-4160.0$ \\
\hline & TST2 & $3837.0-3927.0$ & & $4317.0-4440.0$ & $3975.0-4085.0$ & $3757.0-3807.0$ \\
\hline \multirow[t]{2}{*}{ Sequence 3} & HST3 & $3351.5-3837.0$ & & $3996.0-4317.0$ & $3636.0-3975.0$ & $3341.0-3757.0$ \\
\hline & TST3 & $3310.0-3351.5$ & & $3960.0-3996.0$ & $3610.0-3636.0$ & $3315.0-3341.0$ \\
\hline \multirow[t]{3}{*}{ Sequence 4} & HST4 & $3259.5-3310.0$ & & $3500.0-3960.0$ & $3300.0-3610.0$ & $3209.5-3315.0$ \\
\hline & LSI4 & $3108.0-3259.5$ & & $3324.5-3500.0$ & $3158.0-3300.0$ & $3008.0-3209.5$ \\
\hline & TST4 & $3062.0-3108.0$ & & $3257.0-3324.5$ & $3077.0-3158.0$ & $2960.0-3008.0$ \\
\hline \multirow[t]{3}{*}{ Sequence 5} & HST5 & $2676.0-3062.0$ & & $2935.0-3257.0$ & $2703.0-3077.0$ & $2476.0-2960.0$ \\
\hline & LSI5 & $2565.0-2676.0$ & & $2790.0-2935.0$ & $2604.0-2703.0$ & $2365.0-2476.0$ \\
\hline & TST5 & $2553.0-2565.0$ & & $2757.0-2935.0$ & $2590.0-2604.0$ & $2253.0-2365.0$ \\
\hline \multirow[t]{2}{*}{ Sequence 6} & HST6 & 2553.0-top & not & 2757.0- top not & $2590.0-$ & $2253.0-$ \\
\hline & & identified & & identified & identified & identified \\
\hline
\end{tabular}

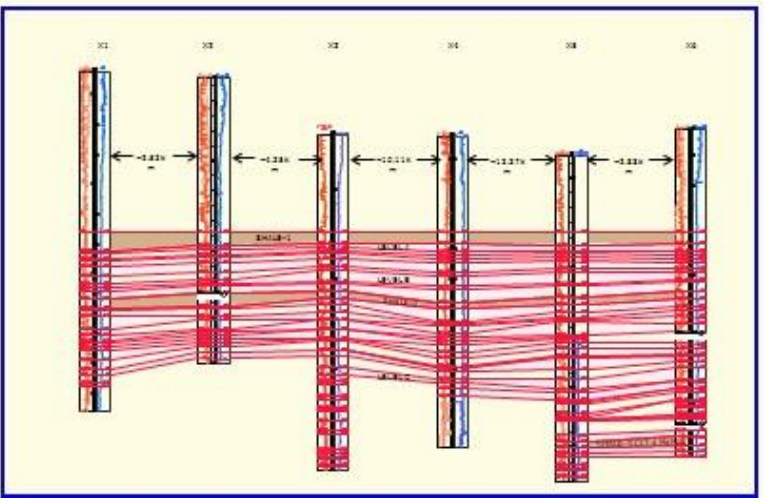

Figure 28: Stratigraphic correlation between wells X1, X2, X3, X4, X5 and X6 


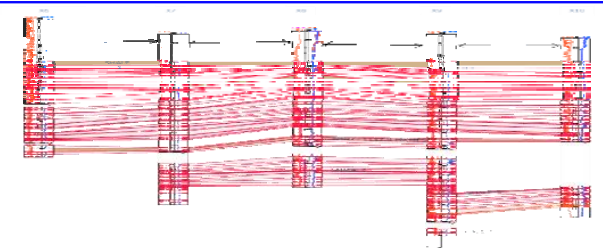

Figure 29: Stratigraphic correlation between wells X6, X7, X8, X9 and X10

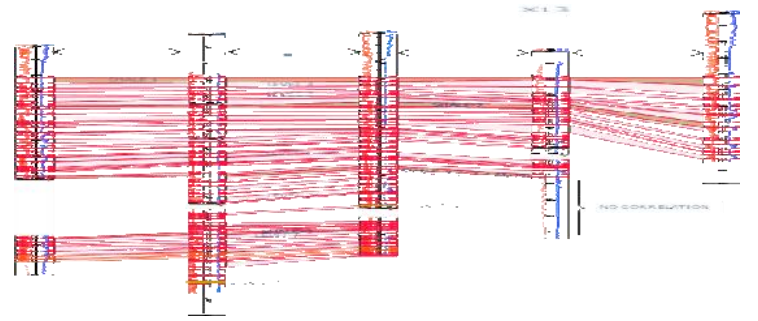

Figure 30: Stratigraphic correlation between wells X10, X11, X12, X13 and X14

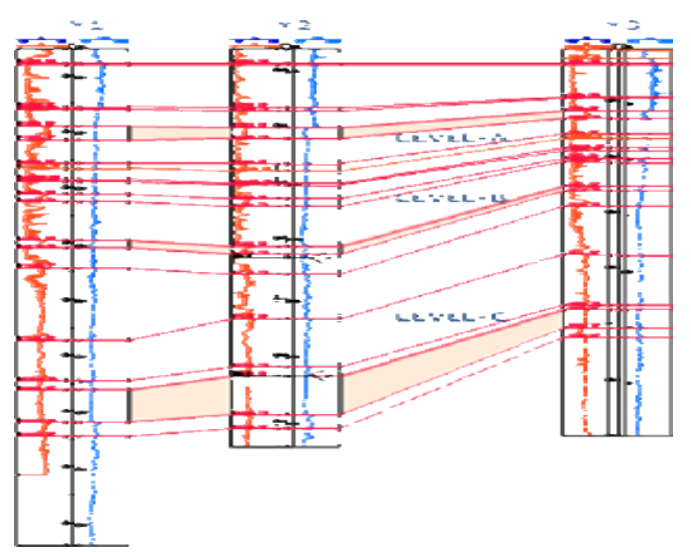

Figure 31: Stratigraphic correlation between wells Y1, Y2 and Y3

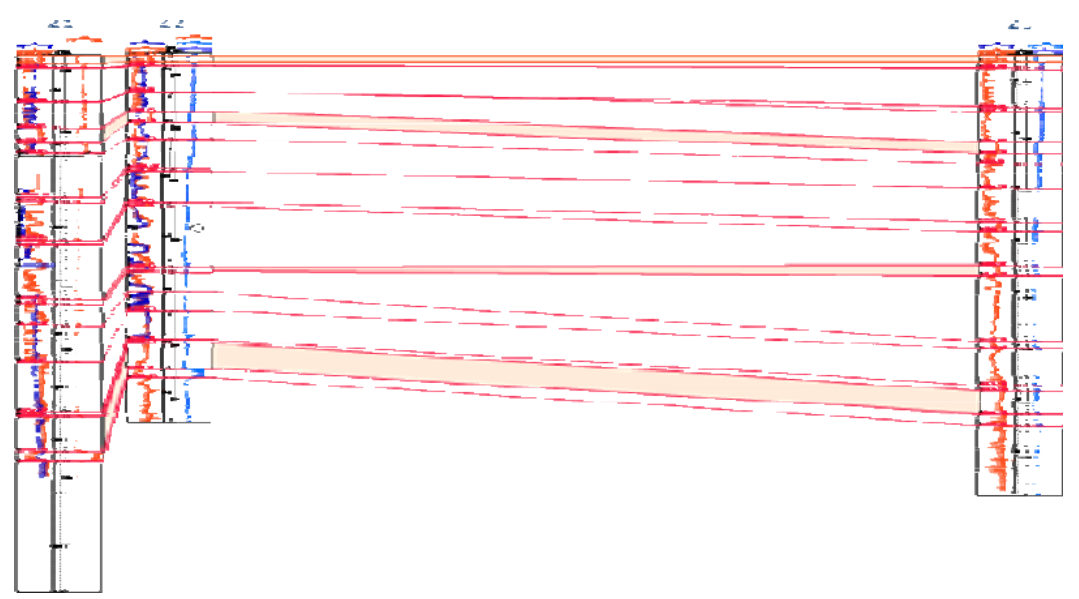

Figure 32: Stratigraphic correlation between Wells Z1, Z2 and Z3

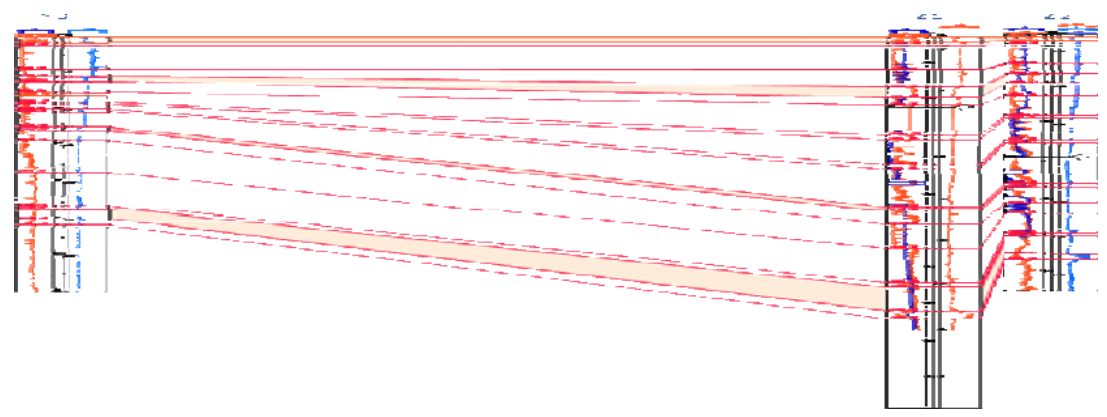

Figure 33: Correlation between Wells Y3, Z1 and Z2 


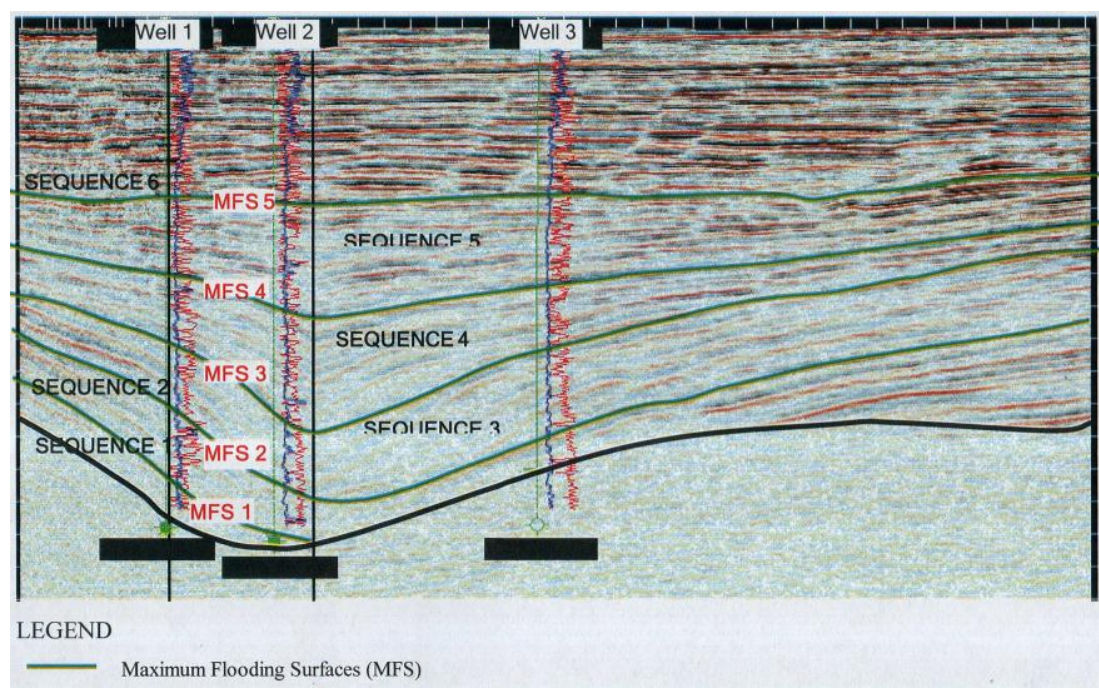

Figure 34: Depositional sequences with maximum flooding surfaces

\section{Sequence 1}

The top of the sequence is marked by the 11.5 Ma maximum flooding surfaces (MFS). The sequence consists of a highstand systems tracts (HST1) and Transgressive systems tracts (TST1) which is a culmination of fining upward unit consisting of landward migrating channel and overbank sands. The reservoir sands consist of blocky aggradational, probably upper shore face sands capped by fining upward parasequence.

\section{Sequence 2}

The top boundary of this sequence is MFS2, 10.4 Ma. It is the largest sequence and consists of upper to lower shore-face sediments with distributary mouth bars and distributary/tidal channel deposits. The sequence consists of a highstand systems tract (HST2) with sediments deposited in a paleo-environment of upper to lower shore-face underlain by tidal flats and tidal channels. The HST grades into transgressive systems tracts (TST2) with alternate sand and shale deposits but generally fining upwards to the condensed section. Good sand bodies coupled with thick sealing hemipelagic shale in this interval could possibly enhance the retention of hydrocarbon.

\section{Sequence 3}

The top boundary of this sequence is MFS3. This is an undated MFS. This sequence is made up of a transgressive systems tract (TST3) and a highstand systems tract (HST3). The TST3 consists of a back-stepping, fming-upwards parasequence set, which terminates on the MFS3 condensed section. This is mainly low energy deposition in inner to outer neritic environment. The sand levels of HST3 are thin and shaly, consisting of a set of coarsening-upwards parasequences. The presence of good sand system within this interval makes a hydrocarbon prolific zone.

\section{Sequence 4}

This sequence lies between MFS3 and MFS4. It consists of a highstand systems tract (HST4), a lowstand systems tract (LST4), and a transgressive systems tract (TST4). HST4 sands are thin and shaly/silty. The water depth is mainly inner neritic. The lowstand systems tract LST4 is made up of blocky, slightly serrated sand units with occasional shale intercalation. These are interpreted as composite channel deposits with overbank shales. LST4 grades into the hemipelagic shales of TST4, whose boundary is the condensed section with MFS4 dated to $9.5 \mathrm{Ma}$. Sequences 3 and 4 together form a 4 th order sequence bounded by the 10.4 Ma MFS and 9.5 Ma MFS. The 9.5 Ma MFS occurs within the shale 3 which is competent cap-rock in the study area. However, this sequence is found to be very prolific considering the good reservoir sand distribution and competent hydrocarbon sealing shale.

\section{Sequence 5}

Sequence 5 is made up of very thick highstand systems tract parasequences (HST5), consisting of coarsening upwards barrier bar sands, and a hemipelagic shale unit (TST5) that has been identified with a major maximum Hooding surface (MFS5). The top boundary of this sequence is TST5. Sediment thickness in this sequence does not vary much across the area. Sedimentation must have been in the aggradational phase where sedimentation rate balances with accommodation space. It is also considered as a possible hydrocarbon bearing interval.

\section{Sequence 6}

This sequence is made up of HST6. It is mainly barrier sands which consist of aggradational packages of sand facies with thin shale intebeds. A varying sand/shale ratio characteristic of the top Agbada sequence dominates the interval. The top boundary of this sequence was not identified due to lack of reliable biostratigraphic data within the shallow interval of the analysed veils. Shale and clay beds occur within the sequence. The foraminiferal recovery was generally very poor and lacked age diagnostic planktic foraminifera.

\subsection{Conclusion}

From the results of the study, the following conclusions are reached:

The gross percentages for sand levels range from $93-96 \%$ in the shallow levels to $60-66 \%$ in the deeper levels. Porosity values ranged between $27 \%$ at shallower sections and $9 \%$ at deeper depths. Six depositional sequences were identified and categorized into their associated system tracts. Porosity decreases with depth in normal compacted formation for both sandstone and shale units. Surface porosity for sandstone is $42 \%$, and for shale it is $38.7 \%$ from extrapolation of sub-surface porosity values to the surface. When this porosity range is matched against well logs, there seems to be a consistent trend tying the range of values to the base of the Benin Formation inferred using only well logs. The depth to the base of Benin Formation is highly variable ranging between 1300 and $2600 \mathrm{~m}$. This study reveals the possibility to correlate sand levels over long distances which enables inferring porosity values laterally. The knowledge of the existent stratigraphic units, the Benin, Agbada and Akata Formations and their petrophysical parameters such as porosity, lateral continuity of the sands and shales, the variation of the net-to-gross of sands with depth, enables the reservoir engineer to develop a plan for the number and location of the wells to be drilled into the reservoir, the rates of production that can be sustained for optimum recovery. The depth to the base of Benin Formation is highly variable ranging between 1300 to $2600 \mathrm{~m}$. Porosity values at the base of the Benin Formation in the study area range from as low as $27 \%$ to as high as $37 \%$. Logs provide reliable porosity data, and additional reservoir level information such as thickness distribution and pore fill. This study reveals the possibility to correlate sand levels over long distances which enables inferring porosity values laterally. Data suggests that the modern Niger Delta has a configuration similar to that of a typical delta model. The delta sequence is mainly a sequence of marine (Akata Formation) clays overlain by paralic (Agbada Formation) sediments, which were finally capped by continental (Benin Formation) gravels and sands. 


\section{Acknowledgement}

The authors are grateful to Nigeria National Petroleum Corporation (NNPC) for provision of data.

\section{References}

[1] S. M. Greenlee, and T. C. Moore, "Recognition and interpretation of depositional sequences and calculation of sea-level changes from stratigraphic data - offshore New Jersey and Alabama Tertiary In: Wilgus C. K. et al. (eds.) Sea-level changes: An integrated approach”, Spec. Publs. Am. Ass. Petrol. Geol., Vol. 42, Pp. 329-353, 1998.

[2] O. Abiola, M. T. Olowokere, and J. S. Ojo, "Sequence Stratigraphy and depositional interpretation: A Case Study of "George" Field, offshore Niger Delta, Nigeria", Petroleum Research, Vol. 3 (1), Pp. 25-32, 2018.

[3] M. C. Kelly, C. M. Skidmore, and R. Cotton, "P-P and P-S angle stack inversion: 69th Ann," Internat. Mtg., Soc. Expl. Geophys., Expanded Abstracts, Pp. $222-223,2000$

[4] S. Jin, G. Cambois, and C. Vuillermoz, "Shear-wave velocity and density estimation from PSwave AVO analysis: application to an OBS dataset from the North Sea.," Geophysics, Vol. 65, Pp. 1446-1454, 2000.

[5] P. R. Vail, R. M. Mitchum Jr. and S. Thompson, "Seismic stratigraphy and global changes of sea-level, part 3 and 4", In: Seismic stratigraphy - Applications to Hydrocarbon Exploration. Memoir \#26 of American Association of Petroleum Geologists, Tulsa, Pp. 63 - 97, 1977.

[6] D. Emery, K. J. Myers, G. T. Bertram, C. M. Griffiths, N. J. Milton, A. D. Reynolds, M. T. Richards, and S. J. Sturrock, Sequence Stratigraphy, Pp. 11-177, 2003.

[7] O. Abiola and M. T. Olowokere, "Seismic facies analysis and depositional process: interpretation of "George" Field, offshore Niger Delta, Nigeria," Journal of Basic Applied Research International, Vol. 13 (4), Pp. 243-252, 2016.

[8] P. R. Vail and W. W. Wornardt, "Well log seismic sequence stratigraphy: an integrated tool for the 90; In: Sequence Stratigraphy as an Exploration Tool: Concepts and Practices from the Gulf Coast," Eleventh Annual Research Conference, Gulf Coast Section, Society of Economic Paleontologists and Mineralogists, Pp. 379 - 388, 1990.

[9] A. Bosellini, "Progradation geometries of carbonate platforms: examples from the Triassic of Dolomites, northern Italy," Sedimentology, Vol. 31, Pp. 124, 1989.

[10] H. W. Posamentier and G. P. Allen, "Variability of the sequence stratigraphic model: effects of local basin factors," Sediment. Geol., Vol. 86, Pp. 91-109, 1993b.

[11] T. S. Alege, "Sequence stratigraphy of Akos Field in the Coastal Swamp Depobelt of the Niger Delta, Nigeria," Advances in Applied Sciences Research, Vol. 8 (1), Pp. 16-27, 2017

[12] P. R. Vail, “Applied sequence stratigraphy course material”, AGIP, Milan Italy, 1991.

[13] T. A. Cross, "Controls on coal distribution in transgressive-regressive cycles, Upper Cretaceous, Western Interior, USA", Soc. Econ. Paleont. Mineral. Spec. Publ. Vol. 42, Pp. 371-380, 1988.

[14] V. D. Robison and M. H. Engel, "Characterization of the source horizons within the Late Cretaceous transgressive sequence of Egypt," AAPG Studies in Geology, Vol. 37, Pp. 101-117, 1993.

[15] D. Tamunosiki, G. H. Ming, L. Wang, E. D. Uko and W. Tamunonengiyeofori, "Petrophysical Characteristics of Coastal Swamp Depobelt Reservoir in the Niger Delta Using Well-Log Data," Journal of Applied Geology and Geophysics, Vol. 2 (2), Pp. 76-85, 2014b.

[16] P. S. Momta and M. I. Odigi, "Sequence Stratigraphic framework and depositional architecture of the Yowi Field, offshore Niger Delta, Nigeria," Journal of Geography, Environment and Earth Science, Vol. 16 (4), Pp. 1-21, 2018.

[17] M. D. Blum, "Climatic and eustatic controls on Gulf Coastal plain fluvial sedimentation: an example from the Late Quaternary of the Colorado River, Texas," Eleventh Annual Research Conference, Gulf Coast Section, Society of Economic Paleontologists and Mineralogists, Pp. 71-83, 1990.

[18] P. N. Southgate, "Reciprocal lowstand clastic and highstand carbonate sedimentation, subsurface Devonian reef complex, Canning Basin, W. Australia," AAPG Mem., Vol. 57, Pp. 157-179, 1993.

[19] O. A. Fatoke and J. P. Bhattacharya, "Controls on depositional systems and Sequence Stratigraphy of the Pliocene-Pleistocene of Eastern Niger Delta, Nigeria," AAPG 2009 Annual Convention and Exhibition, Denver Colorado, 2010.

[20] C. M. Ekweozor and E. M. Daukoru, "Northern delta depobelt portion of the Akata-Agbada petroleum system, Niger Delta, Nigeria, in, Magoon, L. B. and Dow, W. G., (Eds.)," The Petroleum System - From Source to Trap, AAPG Memoir 60: Tulsa, American Association of Petroleum Geologists, Pp. 599-614, 1994.

[21] R. C. Haack, P. Sundararaman and J. Dahl, "Niger Delta petroleum System, in, Extended Abstracts, AAPG/ABGP Hedberg Research Symposium, Petroleum Systems of the South Atlantic Margin, November 16-19, 1997," Rio de Janeiro, Brazil, 1997.

[22] A. Whiteman, “Nigeria: Its Petroleum Geology,” Resources and Potential: London, Graham and Trotman, 1982.

[23] NEDECO, River Studies and Recommendations on Improvement of Niger and Benue. North Holland Publishing Company, 1959.

[24] K. Burke, "Longshore drift, submarine canyons, and submarine fans in development of Niger Delta," American Association of Petroleum Geologists Bull., Vol. 56, Pp. 1975-1983.

[25] J. E. Ejedawe, "Generalized Niger Delta stratigraphy and Lithofacies subdivision; An unpublished report on the Niger Delta submitted to SPDC," Warri, Nigeria, 2007.

[26] J. P. Castagna, M. L. Batzle and R. L. Eastwood, "Relationships between compressional-wave and shear-wavevelocities in clastic silicate rocks," Geophysics, Vol. 50, Pp. 571-581, 1985.

[27] M. J. Wyllie, G. Gregory and H. F. Gardner, "Experimental investigation of factors affecting elastic wave velocity in porous media," Geophysics, Vol. 23, Pp. $459-493,1958$. 